\title{
Nephrotic-Like Proteinuria in Experimental Diabetes
}

\author{
Kerryn A. Greivea Tanya M. Osicka ${ }^{b}$ Leileata M. Russo ${ }^{a}$ \\ Wayne D. Compera \\ aDepartment of Biochemistry and Molecular Biology, Monash University, Clayton and bEndocrine Unit, \\ Austin and Repatriation Medical Center, Heidelberg, Vic., Australia
}

\author{
Key Words \\ Protein degradation - Albumin · Transferrin . \\ Immunoglobulin $\mathrm{G} \cdot$ Radioimmunoassay
}

\begin{abstract}
Aims/Hypothesis: Streptozotocin (STZ) diabetic rats are characterized by the development of albuminuria. It is not known, however, whether the excess excretion of protein is primarily due to intact protein or protein fragments or whether it is specific for albumin or occurs for all high-molecular-weight plasma proteins. To test this we have measured the excretion rates and fractional clearances of $\left[{ }^{14} \mathrm{C}\right]$ albumin, $\left[{ }^{3} \mathrm{H}\right]$ immunoglobulin $\mathrm{G}$ and $\left.{ }^{3} \mathrm{H}\right]$ transferrin in diabetic rats. Methods: The radiolabeled proteins were delivered to the circulation of conscious diabetic (STZ induced for 6 weeks) and control rats by ALZET osmotic pumps. The plasma level of the radiolabeled proteins reached steady-state levels by day 7. Urine and plasma samples from day 7 were used to determine the excretion rates of the proteins by radioactivity and radioimmunoassay. Results: When excretion rates were determined by radioactivity it was apparent that only the albumin excretion rate increased significantly with STZ diabetes to a value of $354 \pm 166 \mu \mathrm{g} / \mathrm{min}$ which agrees with proteinuria determined by Biuret assay of $299.9 \pm 52.4 \mu \mathrm{g} / \mathrm{min}$. The major proportion of protein being excreted was in the form of protein fragments
\end{abstract}

which are not detected by conventional immmunochemical assays. Conclusion: The previously unrecognized nephrotic-like levels of proteinuria in experimental diabetes appears to be associated with an albumin-specific mechanism responsible for the increase in albumin peptides in urine. There was significant lowering of plasma albumin concentration but plasma concentrations of transferrin and immunoglobulin $\mathrm{G}$ remained unchanged. There was also no significant appearance of intact protein in urine that is normally found in nephrotic states.

Copyright @2003S. Karger AG, Basel

\section{Introduction}

Our recent studies in rats [1-7] and in man [8] using tritium-labeled albumin $\left(\left[{ }^{3} \mathrm{H}\right]\right.$ albumin $)$ have demonstrated that albumin, once filtered, is fragmented to small peptides $(<15 \mathrm{kD})$. This is an extremely rapid and efficient process, occurring within minutes and involving lysosomal uptake and regurgitation of peptide products back to the tubular lumen. In healthy rats and man, the albumin-derived fragments represent $>90 \%$ of urinary albumin compared with $<10 \%$ intact albumin. We have also observed that the percentage ratio between intact and fragmented albumin is reversed in both experimental diabetes $[5,6]$ and in patients with type 1 diabetes [8]. Aminoguanidine and ramipril have been demonstrated to nor-

\section{KARGER}

Fax +41613061234 E-Mail karger@karger.ch www.karger.com
C 2003 S. Karger AG, Base

0250-8095/03/0231-0038\$19.50/0

Accessible online at:

www. karger.com/journals/ajn
Dr. Wayne D Comper

Department of Biochemistry and Molecular Biology

Monash University, Wellington Road

Clayton, Vic 3800 (Australia)

Tel. +61 39905 3774, Fax +61 39876 5851, E-Mail wayne.comper@med.monash.edu.au 
malize the fragmentation process in streptozotocin (STZ) diabetic rats $[6,7]$. The exact anatomical location of this 'degradation pathway' has not been determined but it is most likely to occur by endocytosis and lysosomal degradation in proximal tubule cells. Histochemical and electron microscopical studies [9] have shown that following endocytosis, larger molecular weight (MW) proteins are degraded within lysosomes of the epithelial cells in proximal convoluted tubules while ${ }^{125}$ I-labeled BSA has been shown to be degraded by lysates of rat kidney lysosomes [10]. The degradation pathway appears to be nonspecific since all proteins tested to date have been shown to be degraded, including horseradish peroxidase, immunoglobulin $\mathrm{G}(\mathrm{IgG})$ and albumin [1-7], the extent of degradation varying from protein to protein. The pathway will have a profound effect on the measured concentration of protein excretion as existing immunochemical assays do not detect fragments but only intact material $[2,5,7]$.

The extremely rapid lysosomal processing of filtered proteins has not been reproduced in cell culture as it seems cells only in a relatively normal environment exhibit such efficient behavior. However, analogous lysosomal processing of filtered dextran sulfate has been identified where dextran sulfate is comprehensively stripped of its sulfate groups by lysosomal sulfatases during renal passage $[11,12]$. The kinetics of this process are identical to that for lysosomal processing of proteins $[11,12]$.

This paper comprehensively examines the excretion of high MW plasma proteins in experimental diabetes, taking both intact and fragmented forms into account. We examine the excretion rates of albumin, IgG and transferrin in control and STZ-induced diabetic rats exhibiting significant proteinuria using the radioimmunoassay (RIA) analysis, and radioactivity analysis employing tritium- and carbon-14-labeled proteins. Excretion rates of the various proteins as determined by radioactivity were compared to urinary total protein excretion rates as determined by the Biuret method. The conclusion from these studies is that STZ-induced diabetes results in a very high urinary excretion of albumin fragments that accounts for most of the protein-derived material in urine.

\section{Materials and Methods}

\section{Materials}

The Advantage Glucometer was obtained from Roche Diagnostics Australia Pty Ltd (Castle Hill, NSW, Australia). Bovine serum albumin (BSA), rabbit anti-rat transferrin, rabbit anti-rat albumin, bovine IgG, ${ }^{125} \mathrm{I}(10 \mathrm{mCi})$, and STZ were obtained from ICN Biomedicals Inc. (Aurora, Ohio, USA). Ultratard insulin was from Novo
Nordisk Pharmaceuticals Pty Ltd (North Rocks, NSW, Australia). Benzoylated dialysis tubing (MW cut-off 2,000), rat serum albumin (RSA), rat transferrin, rabbit anti-rat $\mathrm{IgG}$, rat $\mathrm{IgG}$, sodium azide, bovine apo-transferrin and thimerosal were obtained from Sigma Chemicals (St. Louis, Mo., USA). Alzet osmotic pumps (model 2001) were obtained from Alza Pharmaceuticals (Palo Alto, Calif., USA). Nembutal $(60 \mathrm{mg} / \mathrm{ml})$ was obtained from Rhone Mirieux Australia Pty Ltd (Pinkenba, Qld., Australia). Sodium boro- $\left[{ }^{3} \mathrm{H}\right]$ hydride (132 $\mathrm{mCi} / \mathrm{mg}$ ), and tritiated water were obtained from NEN Research Products Du Pont (Wilmington, Del., USA). Sephacryl S-300, Sephadex G-100, Sephadex G-25 in PD-10 columns and Blue Dextran T2000 were purchased from Pharmacia Fine Chemicals (Uppsala, Sweden). Filtration membranes (10,000- and 500-MW cut-off) were from Amicon/Millipore (Bedford, Mass., USA). Sheep anti-rabbit antibody was generously supplied by Mr. David Casley of the Department of Medicine, Austin and Repatriation Medical Center, Australia.

\section{Experimental Animals}

Eight-week-old male Sprague-Dawley rats were obtained from the Monash University Central Animal House. Throughout the experimental period they were maintained as pairs, housed in rat boxes under a 12-hour day/night cycle with free access to standard rat chow and water.

\section{Induction of Experimental Diabetes}

Rats were randomly assigned to either the control groups or the diabetic groups. The blood glucose of all rats was tested prior to the induction of diabetes to ensure that all rats were not hyperglycemic. To induce diabetes, the rats were immobilized by towel wrapping and an injection of $50 \mathrm{mg} / \mathrm{kg} \mathrm{STZ}$ was administered via the tail vein. An equivalent volume of citrate buffer $(1 \mathrm{ml} / \mathrm{kg}$, pH 4.5$)$ was administered to all control animals. Hyperglycemia was tested $48 \mathrm{~h}$ after injection of STZ. Rats that obtained a reading $>15 \mathrm{mmol} / \mathrm{l}$ were considered to be diabetic and included in the study. All diabetic rats were administered with $4 \mathrm{U}$ of Ultratard insulin three times a week. Experiments were performed 6 weeks after the induction of diabetes.

\section{Radiolabelling of Proteins}

IgG, RSA and transferrin were tritiated using the reductive methylation technique [13]. Fifty milligrams of either protein was dissolved in $1 \mathrm{ml}$ of $0.2 \mathrm{M}$ sodium borate buffer ( $\mathrm{pH} 8.9$ ) and $0.5 \mathrm{ml}$ of $0.2 M$ paraformaldehyde and $250 \mu \mathrm{l}$ of $0.01 M \mathrm{NaOH}$ containing $25 \mathrm{mCi}$ sodium boro- $\left[{ }^{3} \mathrm{H}\right]$ hydride was added. The preparation was placed on ice for $10 \mathrm{~min}$, then applied to a PD-10 column (pre-equilibrated with phosphate-buffered saline (PBS) $\mathrm{pH}$ 7.4). The polymer peak fraction was collected, placed in benzoylated dialysis tubing and dialyzed against PBS containing $136.9 \mathrm{~m} M \mathrm{NaCl}, 2.68 \mathrm{mM} \mathrm{KCl}$, $8.1 \mathrm{~m} M \mathrm{Na}_{2} \mathrm{HPO}_{4}$ and $1.5 \mathrm{~m} M \mathrm{KH}_{2} \mathrm{PO}_{4}$ at $4^{\circ} \mathrm{C}$ for $4-5$ days. The purity of the protein samples was analyzed using Sephadex G-100.

The RSA was labeled with ${ }^{14} \mathrm{C}$ using a reductive methylation technique modified from Eng [14] using $\left[{ }^{14} \mathrm{C}\right]$ formaldehyde. Twentyfive milligrams of albumin was dissolved in $2.5 \mathrm{ml}$ of buffer containing $100 \mathrm{~m} M$ Hepes pH 7.5, $2 \mathrm{~m} M \mathrm{NiCl}_{2}$ and $20 \mathrm{~m} M \mathrm{NaCNBH}_{3}$. To this mixture was added $125 \mu \mathrm{Ci}$ of $\left[{ }^{14} \mathrm{C}\right]$ formaldehyde and the mixture incubated at $37^{\circ} \mathrm{C}$ for $30 \mathrm{~min}$. Then $1 \mu \mathrm{mol}$ of cold formaldehyde was added and the mixture again incubated at $37^{\circ} \mathrm{C}$ for an additional $90 \mathrm{~min}$. The mixture was then dialyzed against several changes of PBS at $4^{\circ} \mathrm{C}$ until no radioactivity was detected in the 
dialysate. To ensure the purity of the protein sample, it was examined using Sephadex G-100.

The specific activities achieved were: $\left[{ }^{3} \mathrm{H}\right]$ albumin $3.063 \times 10^{7}$ $\mathrm{dpm} / \mathrm{mg},\left[{ }^{14} \mathrm{C}\right]$ albumin $2.02 \times 10^{6} \mathrm{dpm} / \mathrm{mg},\left[{ }^{3} \mathrm{H}\right]$ transferrin $1.921 \times$ $10^{7} \mathrm{dpm} / \mathrm{mg}$, and $\left[{ }^{3} \mathrm{H}\right] \operatorname{IgG} 1.635 \times 10^{7} \mathrm{dpm} / \mathrm{mg}$.

\section{Column Chromatography}

Plasma and urine samples were analyzed using a Sephadex G-100 column (column dimensions $1.8 \times 75 \mathrm{~cm}^{2}$ ) or a Sephacryl S-300 column (column dimensions $2 \times 66 \mathrm{~cm}^{2}$ ). The gels were suspended in PBS, degassed and packed at a flow rate of $80 \mathrm{ml} / \mathrm{h}$ using a Pharmacia LKB Pump P-1. The column was run at $4^{\circ} \mathrm{C}$ with a flow rate of $20 \mathrm{ml} / \mathrm{h}$ and the buffer changed to PBS with $2 \mathrm{mg} / \mathrm{ml}$ of BSA and $0.02 \%$ sodium azide. The column was calibrated using blue dextran $(2 \mathrm{mg} / \mathrm{ml})$ and tritiated water to determine the void volume and the total volume respectively. Ninety-five fractions of $\sim 1.65 \mathrm{ml}$ (G-100) or $\sim 1.45 \mathrm{ml}$ (S-300) were collected with recoveries between 95 and $105 \%$ obtained. The fractional available volume, $\mathrm{K}_{\mathrm{av}}$, was determined by the formula $\left(\mathrm{V}_{\mathrm{e}}-\mathrm{V}_{\mathrm{o}}\right) /\left(\mathrm{V}_{\mathrm{t}}-\mathrm{V}_{\mathrm{o}}\right)$, where $\mathrm{V}_{\mathrm{o}}$ is the void volume, $\mathrm{V}_{\mathrm{e}}$ is the elution volume and $\mathrm{V}_{\mathrm{t}}$ is the total volume of the column.

\section{Long-Term in vivo Administration of Proteins}

The Alzet osmotic pumps, Model 2001, have a mean filling volume of $227 \pm 6 \mu \mathrm{l}$, pumping rate $0.96 \pm 0.04 \mu \mathrm{l} / \mathrm{h}$, length $3 \mathrm{~cm}$, diameter $0.7 \mathrm{~cm}$ and unfilled weight $1.1 \mathrm{~g}$. The osmotic pumps were filled with $\left[{ }^{14} \mathrm{C}\right]$ albumin, $\left[{ }^{3} \mathrm{H}\right] \operatorname{IgG}$ or $\left[{ }^{3} \mathrm{H}\right]$ transferrin, along with $0.002 \% \mathrm{w} / \mathrm{v}$ of thimerosal to inhibit bacterial growth as previously described $[2,4,15,16]$. The pumps were then incubated in PBS with $0.02 \%$ sodium azide to prevent bacterial growth, for $4 \mathrm{~h}$ at $37^{\circ} \mathrm{C}$.

The rats were anesthetized with Nembutal and the osmotic pump was implanted subcutaneously between the scapulae using sterile technique. Each rat received two pumps, one with $\left[{ }^{14} \mathrm{C}\right]$ albumin and one with either $\left[{ }^{3} \mathrm{H}\right] \operatorname{IgG}$ or $\left[{ }^{3} \mathrm{H}\right]$ transferrin. The rats were then maintained as pairs in rat boxes, being placed in metabolic cages on days 2, 5 and 7 after pump implantation with free access to food and water at all times. Twenty-four-hour urine samples were collected on days 2, 5 and 7 and corresponding plasma samples taken. Both blood and urine samples were centrifuged at $3000 \mathrm{rpm}$ in a KS-5200 C Kubota benchtop centrifuge for $10 \mathrm{~min}$ and then analyzed for radioactivity. On day 7, the animals were anesthetized, sacrificed by cardiac punc- ture and the kidneys excised. Glomerular filtration rate (GFR) was determined by the creatinine assay [17]. The urine flow rate (UFR) was determined by measuring the volume of the 24-hour urine collection in milliliters.

\section{Determination of Whole Kidney Uptake of Radiolabeled Material}

To determine the whole kidney uptake of radiolabeled material, the excised kidneys were weighed, minced, placed into 10-ml centrifuge tubes and $1.4 \mathrm{M} \mathrm{NaOH}$ added to make the volume $6 \mathrm{ml}$. The tube was suspended in boiling water for 15-30 min to allow digestion to occur. To determine radioactivity content of the digest, $100 \mu \mathrm{l}$ of the digest was added to $50 \mu \mathrm{l}$ of hydrogen peroxide in scintillation vials, to decolorize the solution. The solution was made up to $1 \mathrm{ml}$ with $850 \mu \mathrm{l}$ of water. Four milliliters of scintillation fluid was added and the vials were stored overnight in the dark to reduce chemiluminescence. The samples were then counted for radioactivity.

\section{Determination of Catabolic Rate of Albumin}

This was determined by injecting $750 \mu$ l containing $1 \times 10^{7} \mathrm{dpm}$ of $\left[{ }^{14} \mathrm{C}\right]$ albumin into the tail vein. Blood samples were obtained 1,2 , 4 and $24 \mathrm{~h}$ from the tail vein. Total albumin clearance was calculated from the decrease in log plasma radioactivity over the 2- to 24-hour period [18] (regression coefficient $>0.98$ ) assuming the total albumin pool is $563 \mathrm{mg} / 100 \mathrm{~g}$ body weight [19].

\section{Albumin Radioimmunoassay}

The RIA utilized ${ }^{125}$ I-labeled RSA, prepared using the Chloramine-T method [20], rabbit antiserum (polyclonal) to rat albumin and sheep anti-rabbit antibodies. The urinary albumin concentration measured by this double antibody RIA had an interassay coefficient of variation of $7 \%$ at a concentration of $180 \mathrm{ng} / \mathrm{ml}$. The detection limit of the assay was $31.2 \mathrm{ng} / \mathrm{ml}$. The standard curve was prepared using a RSA standard $(1 \mathrm{mg} / \mathrm{ml})$ which was diluted to give a range of 4,000 to $31.2 \mathrm{ng} / \mathrm{ml}$. The first antibody was diluted to $1 / 6,000$ and the second antibody was diluted to $1 / 40$.

\section{Immunoglobulin G Radioimmunoassay}

The RIA utilized ${ }^{125} \mathrm{I}$-labeled rat serum $\mathrm{IgG}$, prepared according to the Chloramine-T method [20] using $10 \mu \mathrm{l}$ of a $1 \mathrm{mg} / \mathrm{ml} \mathrm{IgG} \mathrm{stan-}$

Table 1. Physiological parameters of the 6-week STZ-induced diabetics and age-matched controls at day 7 of the osmotic pump implantation (fractional clearances determined for $\left[{ }^{14} \mathrm{C}\right]$ albumin were in rats with osmotic pumps containing either $\left[{ }^{3} \mathrm{H}\right] \operatorname{IgG}$ or $\left[{ }^{3} \mathrm{H}\right] \operatorname{transferrin}$ )

\begin{tabular}{|c|c|c|c|c|c|c|}
\hline Group & Weight, g & $\begin{array}{l}\text { Blood glucose } \\
\mathrm{mmol} / \mathrm{l}\end{array}$ & $\begin{array}{l}\text { Glomerular } \\
\text { filtration rate } \\
\mathrm{ml} / \mathrm{min}\end{array}$ & $\begin{array}{l}\text { Urine flow rate } \\
\mathrm{ml} / \mathrm{min} / 10^{-2}\end{array}$ & $\begin{array}{l}\text { Fecal } \\
\text { weight, g }\end{array}$ & $\begin{array}{l}\text { Kidney } \\
\text { weight, g }\end{array}$ \\
\hline \multicolumn{7}{|l|}{ 6-Week diabetics } \\
\hline$\left[{ }^{3} \mathrm{H}\right] \operatorname{IgG}(\mathrm{n}=7)$ & $238.8 \pm 40.9^{*}$ & $21.5 \pm 3.4^{*}$ & $2.2 \pm 0.1$ & $6.6 \pm 0.2^{*}$ & $28.7 \pm 0.6^{*}$ & $1.4 \pm 0.2$ \\
\hline$\left[{ }^{3} \mathrm{H}\right]$ transferrin $(\mathrm{n}=7)$ & $272.3 \pm 19.9 *$ & $21.7 \pm 3.6^{*}$ & $2.6 \pm 0.6$ & $6.3 \pm 1.2 *$ & $31.3 \pm 2.3 *$ & $1.6 \pm 0.1^{\#}$ \\
\hline \multicolumn{7}{|l|}{ 6-Week controls } \\
\hline$\left[{ }^{3} \mathrm{H}\right] \operatorname{IgG}(\mathrm{n}=7)$ & $402.3 \pm 45.5$ & $5.9 \pm 0.7$ & $2.3 \pm 0.1$ & $1.1 \pm 0.1$ & $12.6 \pm 1.1$ & $1.3 \pm 0.1$ \\
\hline$\left[{ }^{3} \mathrm{H}\right]$ transferrin $(\mathrm{n}=7)$ & $419.8 \pm 15.2$ & $4.6 \pm 0.3$ & $2.3 \pm 0.5$ & $1.0 \pm 0.3$ & $14.7 \pm 0.8$ & $1.4 \pm 0.2$ \\
\hline
\end{tabular}

$\# \mathrm{p}<0.05, * \mathrm{p}<0.001$ 
dard, rabbit antiserum (polyclonal) to rat IgG, sheep anti-rabbit antibodies and non-immune rabbit serum. The detection limit of the assay was $31.2 \mathrm{ng} / \mathrm{ml}$. The standard curve was prepared using a rat serum $\mathrm{IgG}$ standard $(1 \mathrm{mg} / \mathrm{ml})$ which was diluted to give a range of 4,000 to $31.2 \mathrm{ng} / \mathrm{ml}$. The first antibody was diluted to $1 / 16,000$ and the second antibody was diluted to $1 / 40$.

\section{Transferrin Radioimmunoassay}

The RIA utilized ${ }^{125} \mathrm{I}$-labeled rat serum transferrin, prepared according to the Chloramine-T method [20] using $10 \mu \mathrm{l}$ of a $1 \mathrm{mg} / \mathrm{ml}$ transferrin standard, rabbit antiserum (polyclonal) to rat transferrin, sheep anti-rabbit antibodies and non-immune rabbit serum. The detection limit of the assay was $6 \mathrm{ng} / \mathrm{ml}$. The standard curve was prepared using a rat serum $\mathrm{IgG}$ standard $(1 \mathrm{mg} / \mathrm{ml})$ which was diluted to give a range of 1,600 to $6 \mathrm{ng} / \mathrm{ml}$. The first antibody was diluted to $1 / 20,000$ and the second antibody was diluted to $1 / 40$.

\section{Urine Protein Analysis}

Urinary protein was measured by the Biuret assay [21] and by the BCA protein assay kit (Pierce, Rockford, Ill., USA). Since the presence of glucose in the urine sample from diabetic rats severely inter-

Table 2. Concentration of radiolabeled material in the kidneys $(\mathrm{dpm} / \mathrm{g})$ and plasma $(\mathrm{dpm} / \mathrm{ml})$ of the 6-week STZ-induced diabetics and age-matched controls

\begin{tabular}{lcc}
\hline Group & Kidney/105 & Plasma/105 \\
\hline 6-Week diabetics & & \\
{$\left[{ }^{14} \mathrm{C}\right]$ albumin $(\mathrm{n}=14)$} & $0.13 \pm 0.02$ & $0.12 \pm 0.04$ \\
{$\left[{ }^{3} \mathrm{H}\right] \operatorname{IgG}(\mathrm{n}=7)$} & $6.3 \pm 1.5$ & $6.3 \pm 0.9$ \\
{$\left[{ }^{3} \mathrm{H}\right]$ transferrin $(\mathrm{n}=7)$} & $8.7 \pm 1.6$ & $6.8 \pm 0.9$ \\
\hline 6-Week controls & & \\
{$\left[{ }^{14} \mathrm{C}\right]$ albumin $(\mathrm{n}=14)$} & $0.15 \pm 0.03$ & $0.12 \pm 0.02$ \\
{$\left[{ }^{3} \mathrm{H}\right] \operatorname{IgG}(\mathrm{n}=7)$} & $5.5 \pm 0.8$ & $5.4 \pm 0.9$ \\
{$\left[{ }^{3} \mathrm{H}\right]$ transferrin $(\mathrm{n}=7)$} & $10.0 \pm 0.8$ & $5.3 \pm 0.6$ \\
\hline
\end{tabular}

fered with the Biuret assay, it was necessary to perform a 1/10 dilution of the urine sample to remove the contaminating effect of the glucose. The BCA could not be used on the pretreated or diluted diabetic samples.

\section{Counting of Radioactivity}

Tritium and carbon-14 radioactivity was determined in 1-ml aqueous samples with $3 \mathrm{ml}$ scintillant [22] and recorded on a Wallac 1409 liquid scintillation counter (Wallac, Turku, Finland).

\section{Statistics}

All values are represented as mean \pm SD unless otherwise stated, where $\mathrm{n}$ is the number of determinations. Student's t-test was used to determine probability.

\section{Results}

The physiological parameters of the rats were normal and in accordance with published data. There was a significant difference between all control groups and diabetic groups in body weight, blood glucose, UFR and feces weight (table 1). Upon sacrifice of the rats, the kidneys were removed and analyzed for accumulation of radiolabeled material (table 2). No significant accumulation was found, with the levels of radiolabeled material similar to that existing in the plasma. The levels of radioactivity found in urine, plasma and whole kidneys reached steady state at day 7 for all labeled proteins used as previously demonstrated $[2,4]$. The percentage of labeled material released by the osmotic pump recovered in the plasma, urine and in the kidneys at day 7 was in the range of $6.5-$ $14.2 \%$ for albumin, $5.1-6.5 \%$ for transferrin and 2.9 $3.9 \%$ for IgG (table 3). Studies on the turnover of a bolus injection of labeled albumin have demonstrated that most

Table 3. Radiolabeled tracer released in the course of a 7-day osmotic pump infusion and the percentage of the infused material recovered in the urine. For whole-body determinations, plasma volume was considered to be $8 \mathrm{ml}$, kidney weight was $1.4 \mathrm{~g}$ and urine volumes are set out in table 1

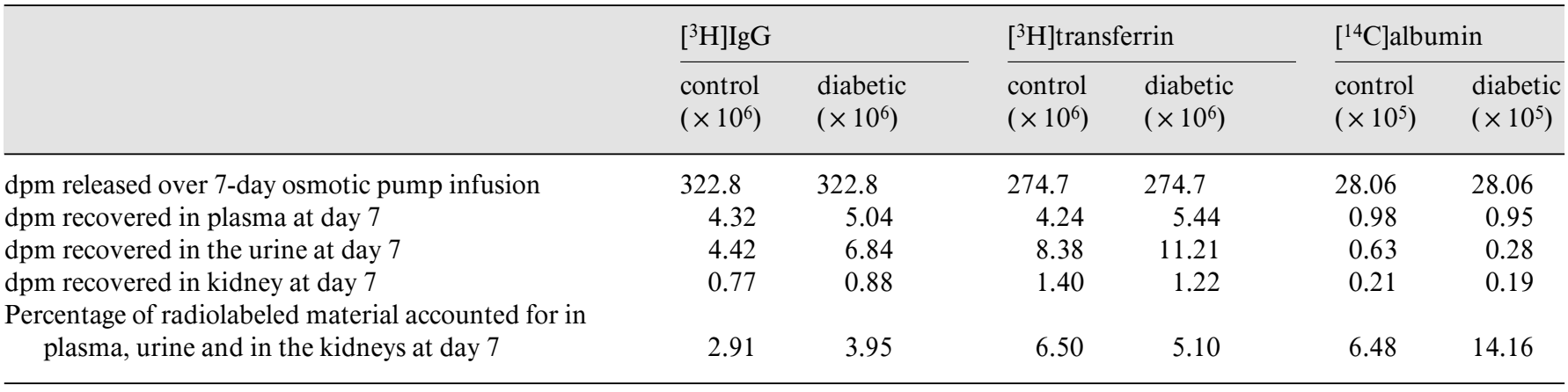




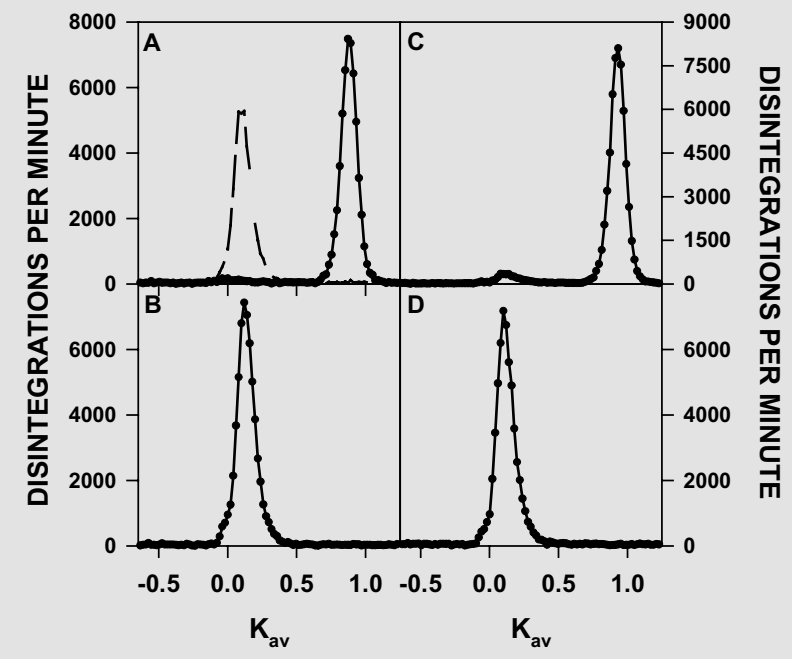

1

Fig. 1. Sephadex G-100 profiles of $\left[{ }^{14} \mathrm{C}\right]$ albumin in the urine and plasma of the 6-week STZ-induced diabetics and age-matched controls. A Control urine (79,000 dpm loaded), broken lines denote original albumin stock solution (71,000 dpm loaded). B Control plasma (59,000 dpm loaded). C Diabetic urine (67,000 dpm loaded). D Diabetic plasma (65,000 dpm loaded).

Fig. 2. Sephadex G-100 profiles of $\left[{ }^{3} \mathrm{H}\right] \mathrm{IgG}$ in the urine and plasma of the 6-week STZ-induced diabetics and age-matched controls. A Control urine (118,000 dpm loaded), broken lines denote original IgG stock solution (130,000 dpm loaded). B Control plasma (156,000 dpm loaded) (inset shows control plasma run on Sephacryl S-300). C Diabetic urine (47,000 dpm loaded). D Diabetic plasma (126,000 dpm loaded) (inset shows control plasma run on Sephacryl S-300).

Fig. 3. Sephadex G-100 profiles of $\left[{ }^{3} \mathrm{H}\right]$ transferrin in the urine and plasma of the 6-week STZ-induced diabetics and age-matched controls. A Control urine (120,000 dpm loaded), broken line denotes original transferrin stock solution $(151,000 \mathrm{dpm}$ loaded). B Control plasma $(92,000 \mathrm{dpm}$ loaded). C Diabetic urine $(117,000 \mathrm{dpm}$ loaded). D Diabetic plasma (172,000 dpm loaded).

of the material is retained by muscle as compared to other body tissues [unpubl. data].

Size exclusion analysis (fig. 1-3) showed that all three proteins were intact in the original stock solution; the radiolabeled material in the plasma at day 7 was also intact. There was no low MW material present in the plasma samples. The urine profiles showed that most of the excreted radiolabeled protein was degraded into small fragments with only a small percentage of intact material excreted.

The concentration of plasma proteins as determined by RIA and the urinary excretion of radiolabeled material at day 7 is listed in table 4 . The plasma concentration of
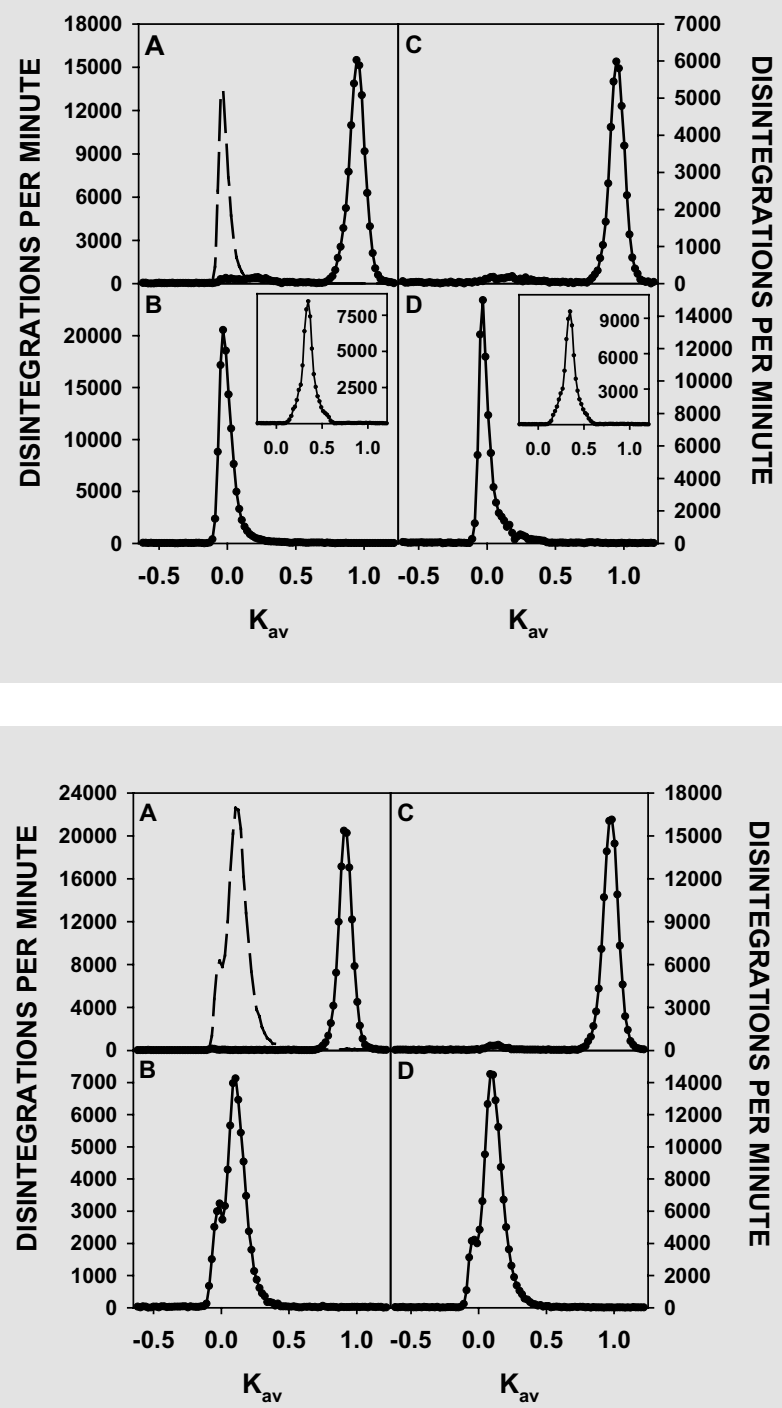

albumin was lowered but there was no significant lowering of plasma transferrin and IgG. The relatively high excretion rates of albumin, estimated from radioactivity, are found to be much greater than those estimated by RIA. Similar differences were observed for transferrin and $\mathrm{IgG}$. This is due to the fact that most of the excreted material is in degraded fragment form and that these fragments are not detected by the RIA method $[4,5,7]$.

The high excretion rate of albumin as determined by radioactivity is in accord with total protein excretion rate as determined by the Biuret assay for the control $44.1 \pm$ $2.4 \mu \mathrm{g} / \mathrm{min}(\mathrm{n}=7)$ and diabetic rats as $299.9 \pm 52.4 \mu \mathrm{g} /$ $\min (\mathrm{n}=7)$ and as determined by the BCA assay for the 
Table 4. Concentration of plasma proteins as determined by RIA and the urinary excretion of the tracers, $\left[{ }^{14} \mathrm{C}\right]$ albu$\min ,\left[{ }^{3} \mathrm{H}\right] \mathrm{IgG}$ and $\left[{ }^{3} \mathrm{H}\right]$ transferrin

\begin{tabular}{|c|c|c|c|c|}
\hline Group & $\begin{array}{l}\text { Plasma } \\
\text { concentration } \\
\mathrm{mg} / \mathrm{ml}\end{array}$ & $\begin{array}{l}\text { Urinary excretion } \\
\mathrm{dpm} / \mathrm{min}\end{array}$ & $\begin{array}{l}\text { Excretion rate } \\
\text { by radioactivity } \\
\mu \mathrm{g} / \mathrm{min}^{1}\end{array}$ & $\begin{array}{l}\text { Excretion rate } \\
\text { by RIA } \\
\mu \mathrm{g} / \mathrm{min}^{2}\end{array}$ \\
\hline \multicolumn{5}{|l|}{ 6-Week diabetics } \\
\hline Albumin $(n=14)$ & $22.3 \pm 3.2 *$ & $197.5 \pm 35.8^{*}$ & $354.7 \pm 166.6^{*}$ & $0.65 \pm 0.37 * * *$ \\
\hline $\operatorname{IgG}(n=7)$ & $3.4 \pm 1.1$ & $4,747.7 \pm 451.8^{*}$ & $22.5 \pm 10.1$ & $0.12 \pm 0.04 * * *$ \\
\hline Transferrin $(n=7)$ & $3.0 \pm 0.3$ & $7,786.1 \pm 921.3^{* *}$ & $35.2 \pm 7.8$ & $0.100 \pm 0.06^{* * *}$ \\
\hline \multicolumn{5}{|l|}{ 6-Week controls } \\
\hline Albumin $(n=14)$ & $27.2 \pm 2.3$ & $43.6 \pm 5.5$ & $97.0 \pm 19.3$ & $0.36 \pm 0.19$ \\
\hline $\operatorname{IgG}(n=7)$ & $3.7 \pm 1.1$ & $3,063.5 \pm 625.0$ & $26.4 \pm 14.8$ & $0.08 \pm 0.01$ \\
\hline Transferrin $(n=7)$ & $3.2 \pm 0.3$ & $5,822.1 \pm 1393.3$ & $35.5 \pm 10.3$ & $0.04 \pm 0.02$ \\
\hline \multicolumn{5}{|c|}{$\begin{array}{l}1 \text { Excretion rate by radioactivity }(\mu \mathrm{g} / \mathrm{min})=\text { Fractional clearance by radioactivity } \times \text { GFR } \times \text { Plasma concentration } \\
(\mu \mathrm{g} / \mathrm{ml}) \text {. }\end{array}$} \\
\hline
\end{tabular}

control of $95.3 \pm 13.1 \mu \mathrm{g} / \mathrm{min}(\mathrm{n}=7)($ table 5$)$ (the BCA assay on diabetic urine was not performed as this assay is extremely sensitive to contamination by glucose). The protein estimates can only be regarded as semiquantitative as it is likely that chromogen formation for low MW peptides is poor. Most of the proteinaceous material has a MW between 500 and 10,000 Da. When normal rat urine is filtered through an Amicon/Millipore membrane (MW cut-off $10,000 \mathrm{Da})$ it results in the recovery of $98.6 \pm$ $0.1 \%(\mathrm{n}=5)$ of the Biuret material in the filtrate whereas for diabetic samples recovery was $97.3 \pm 0.9 \%(n=5)$. Filtration through a 500-MW cut-off membrane retained $85.2 \pm 9.8 \%(\mathrm{n}=5)$ of the Biuret material for control urine and $89.7 \pm 5.8 \%(\mathrm{n}=5)$ for diabetic urine.

The data in table 4 are used to calculate the FC (= [urine concentration of protein][UFR $] /[$ plasma concentration of protein][GFR]) of the labeled proteins in the control and diabetic groups by either radioactivity or RIA. By radioactivity, no significant difference in the FC of either the $\left[{ }^{3} \mathrm{H}\right] \mathrm{IgG}$ or $\left[{ }^{3} \mathrm{H}\right]$ transferrin was found between the diabetics and controls (fig. 4) whereas there was a significant increase for $\left[{ }^{14} \mathrm{C}\right]$ albumin. By RIA the FC of all three labeled proteins was several orders of magnitude less than the FC as determined by radioactivity, and a significant difference between the control and the diabetic groups was apparent for all three of the labeled proteins (fig. 5).

For experiments with non-filtering kidneys the plasma contained $2 \times 10^{6} \mathrm{dpm} / \mathrm{ml}$ of $\left[{ }^{3} \mathrm{H}\right]$ albumin at $4 \mathrm{~h}$. When
Table 5. Excretion rates of albumin by RIA and radioactivity as compared with the urinary total protein excretion (UTP) as determined by the Biuret assay for controls and 6-week STZ-induced diabetic rats

\begin{tabular}{lll}
\hline & $\begin{array}{l}\text { Controls } \\
\mu \mathrm{g} / \mathrm{min}\end{array}$ & $\begin{array}{l}\text { Diabetics } \\
\mu \mathrm{g} / \mathrm{min}\end{array}$ \\
\hline $\begin{array}{l}\text { Albumin excretion rate by } \\
\quad \text { radioactivity }(\mathrm{n}=14)\end{array}$ & $97.1 \pm 19.3$ & $354.7 \pm 166.6$ \\
$\begin{array}{l}\text { UTP excretion rate by Biuret } \\
\text { assay }(\mathrm{n}=7)\end{array}$ & $44.1 \pm 2.4$ & $299.9 \pm 52.4$ \\
$\begin{array}{c}\text { UTP excretion rate by BCA } \\
\text { assay (n }=7)\end{array}$ & $95.3 \pm 13.1$ & $\mathrm{n} / \mathrm{a}$ \\
$\begin{array}{c}\text { Albumin excretion rate by RIA } \\
(\mathrm{n}=14)\end{array}$ & $0.36 \pm 0.19$ & $0.65 \pm 0.37$ \\
\hline & &
\end{tabular}

analyzed on Sephadex G-100 (loading quantity 100,000 $\mathrm{dpm}$ ) there was no low MW material present (not shown). If the kidneys had been filtering normally we would have expected at least 720,000 dpm of radiolabeled material (mostly fragments) in urine. The fact that no radiolabeled fragments were observed in the 4-hour plasma provides direct evidence that albumin fragments in urine are produced specifically by the kidney and not by extrarenal sources.

The high excretion rates for albumin-derived material are also in accord with total albumin clearance as measured by the disappearance of radiolabeled plasma albu- 


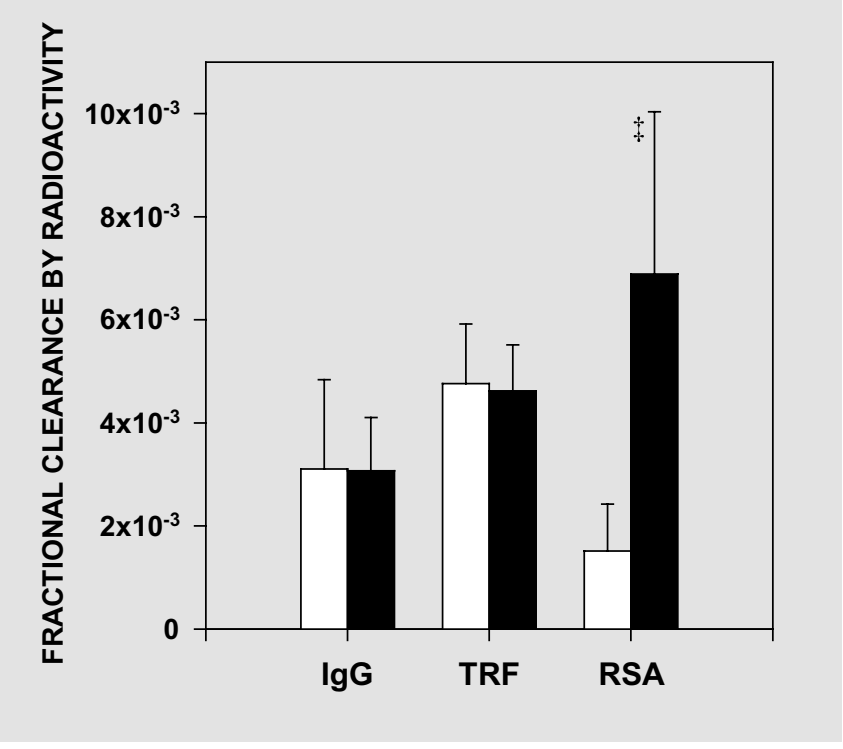

Fig. 4. Fractional clearance of $\left[{ }^{3} \mathrm{H}\right] \operatorname{IgG~G}(n=7),\left[{ }^{3} \mathrm{H}\right] \operatorname{transferrin}(\mathrm{n}=$ 7) and $\left[{ }^{14} \mathrm{C}\right]$ albumin $(\mathrm{n}=14)$ by radioactivity in 6 -week STZ-induced diabetic rats $(\square)$ and age-matched controls $(\square) . \neq p<0.001$

min. For controls $(n=4)$, total albumin clearance was $7.93 \pm 1.01 \mathrm{mg} 100 \mathrm{~g}$ body weight ${ }^{-1} \cdot \mathrm{h}^{-1}($ mean $\pm \mathrm{SE})$ whereas for 6-week STZ rats it was $10.92 \pm 0.73 \mathrm{mg} 100 \mathrm{~g}$ body weight ${ }^{-1} \cdot \mathrm{h}^{-1}$. These clearances are far higher than clearance of albumin-derived material in urine (table 5) calculated to be for control $\sim 2.37 \mathrm{mg} 100 \mathrm{~g}$ body weight $^{-1} \cdot \mathrm{h}^{-1}$ and for 6 -week STZ rats $4.68 \mathrm{mg} 100 \mathrm{~g}$ body weight $^{-1} \cdot \mathrm{h}^{-1}$.

\section{Discussion}

The striking new feature of these results with STZ diabetic rats is that their proteinuria is approaching nephrotic states comparable to that obtained in anti-glomerular basement glomerulonephritis (anti-GBM GN) and puromycin aminonucleoside nephritis (PAN) [23-25]. There are, however, major differences with classic nephrosis in terms of (1) there is no major decrease in plasma protein concentration other than for albumin; (2) that excreted protein is in the form of protein fragments as compared to the intact protein found in nephritis [23-25], and (3) the fractional clearance of albumin, which is the only protein whose fractional clearance increases in STZ diabetes, is still considerably lower than the fractional clearance of albumin measured for anti-GBM and PAN [23-25]. It is

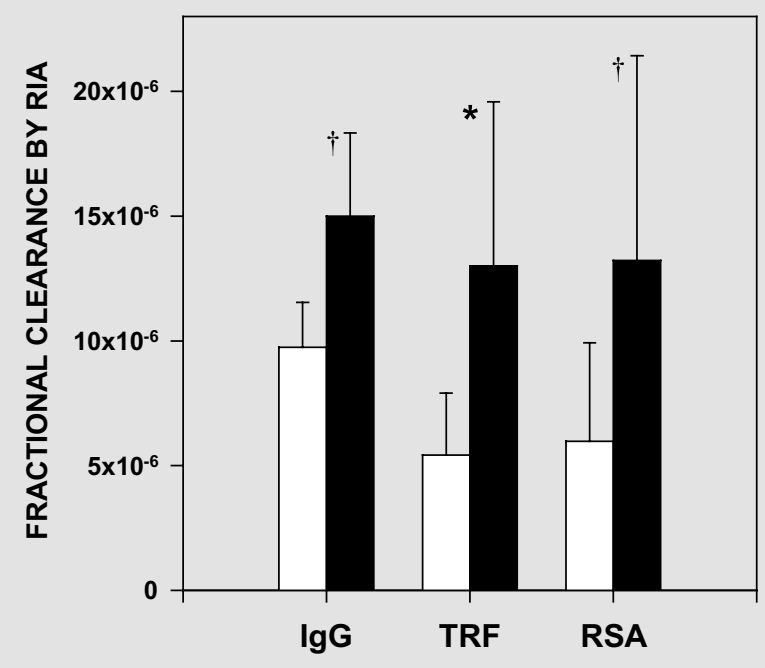

Fig. 5. Fractional clearance of $\operatorname{IgG} G(n=7)$, transferrin $(n=7)$ and albumin $(n=14)$ by RIA in 6-week STZ-induced diabetic rats $(\boldsymbol{\square})$ and age-matched controls $(\square){ }^{*} \mathrm{p}<0.05 ;{ }^{\dagger} \mathrm{p}<0.01$.

apparent that factors responsible for the specific increase in albumin fragment excretion in STZ diabetic rats are related to the simultaneous decrease in the plasma albumin concentration and not due to increases in plasma volume (and therefore dilution of plasma proteins) as found in chronic renal failure [19].

An issue reconfirmed by this study is the inability of the RIA to detect the significant peptiduria occurring in STZ diabetic rats. This is not surprising as recent work has shown that the RIA can only detect intact albumin [5, 7] and that an ELISA can only detect IgG in its intact form [4]. Therefore, these immunochemical-based assays do not detect a significant amount of filtered protein from normal kidneys. When determined by RIA the fractional clearance of albumin, IgG and transferrin was several orders of magnitude less than that determined by radioactivity. This demonstrates that the RIA is generally unable to detect much of the excreted protein, yet this assay and similar immunochemically based assays, such as radial immunodiffusion [26], immunoprecipitation [27], the Micral-Test II [28], immunonephelometry [29] and some gel electrophoretic techniques have been widely used to assess the relative excretion rates of albumin, transferrin and $\mathrm{IgG}$ in the published comparative studies performed with healthy and diseased kidneys. 
The actual mechanism of the specific increase in albumin excretion in STZ diabetic rats is not known but there are some important observations that may contribute to our understanding. Urinary peptides do not arise from extrarenal degradation as (i) they are not observed in plasma, and (ii) do not accumulate in plasma in rats with nonfiltering kidneys. The specific increase in albumin excretion could not be explained by a decrease in the 'chargeselective' properties of the GCW as there is growing evidence that the GCW or the GBM does simply not exhibit charge selectivity and that transglomerular passage is determined by size selectivity alone [3, 11, 30-33]. Rath$\mathrm{er}$, the specific increase in the fractional clearance of albumin could be explained by a progressive inhibition of the recently discovered albumin retrieval pathway [34]. As the pathway appears to be exclusive for albumin, and large quantities of albumin are filtered by the GCW, any alterations in the functioning of this pathway will have a significant effect on the fractional clearance of albumin. With less than normal uptake by the retrieval pathway the albumin is able to interact with the degradation pathway. The degradation pathway is distal to the retrieval pathway. This results in the relatively large quantities of fragmented albumin being excreted. Other proteins such as transferrin and IgG were unaffected. Disruptions in the retrieval and degradation pathway observed in diabetes may be modulated through increased glucose levels, which have been shown to effect protein uptake and degradation in the kidney [35-37] with insulin treatment restoring uptake [35].

By radioactivity analysis the fractional clearance of $\mathrm{IgG}$ and transferrin did not increase significantly but the fractional clearance of albumin did increase significantly for 6-week STZ-induced diabetic rats. This is supported by the fact that the increase in urinary total protein excretion rate could be accounted for simply by the increase in the albumin excretion rate. The major reason for this increase is due to the increased excretion rate of fragmented albumin determined by the difference in excretion rate calculated by radioactivity and excretion rate by RIA in table 4. Studies on kidney uptake of radiolabeled proteins demonstrated that the levels of radioactivity in the kidney came to steady state over the 7-day period, that there was no significant accumulation of tracer, and that there was no significant difference in the uptake in controls versus diabetic rats. These studies demonstrate therefore that the glomerular permeability to transferrin and $\mathrm{IgG}$ is essentially unaltered and that the specific increase in the fractional clearance of albumin appears to be due to non-glomerular factors, such as the retrieval pathway, particularly as glomerular size selectivity alterations are always amplified by relatively large increases in the fractional clearance of transport probes with larger molecular radii.

The increases in the excretion of albumin-derived fragments to high levels is still well within the range of total albumin clearance by the rat. In fact, normal total albumin clearance is so high that the plasma albumin pool in a rat is essentially cleared with in $24 \mathrm{~h}$ [19]. The level of albumin clearance measured for our controls $(7.9 \mathrm{mg}$ $100 \mathrm{~g}$ body weight $\left.^{-1} \cdot \mathrm{h}^{-1}\right)$ as measured with $\left[{ }^{14} \mathrm{C}\right]$ albumin was similar to that measured previously using $\left[{ }^{125} \mathrm{I}\right] \mathrm{albu}-$ min of $4.5 \mathrm{mg} 100 \mathrm{~g}$ body weight ${ }^{-1} \cdot \mathrm{h}^{-1}$ [19].

Although there is no increase in the fractional clearance of total (intact plus fragments) $\mathrm{IgG}$ and transferrin at 6 weeks' STZ-induced diabetes, there is a significant increase in the fractional clearance of IgG and transferrin as detected by RIA. There is much evidence to suggest that the renal degradation of filtered proteins occurs in the lysosomes of the proximal tubules and lysosomal activity and/or trafficking to the lysosomes has been shown to decrease with the progression of experimental diabetes [5-7, 35-38]. A reduction in the lysosomal activity/trafficking would account for the reduction in the degradation of IgG and transferrin, and the apparent increase in FC by RIA, with no increase in the glomerular sieving.

The clinical importance of the recognition of a completely different protein excretion pattern as measured by radioactivity and total protein assays as compared to immunochemical assays focuses on (i) the hitherto unrecognized pathological consequences of the peptiduria, and (ii) how proteinuria is defined, and measured in terms of the efficacy of drugs used to inhibit proteinuria in diabetic nephropathy.

\section{Acknowledgments}

We would like to thank Ms Lynette Pratt from the Department of Biochemistry and Molecular Biology, Monash University, Victoria, Australia, for her excellent technical assistance and Mr Steve Sastra from the Endocrinology Unit of the ARMC, Heidelberg, Victoria, Australia, for his technical assistance with the radioimmunoassays. 


\section{References}

1 Osicka TM, Comper WD: Protein degradation during renal passage in normal kidneys is inhibited in experimental albuminuria. Clin Sci 1997;93:65-72.

2 Osicka TM, Panagiotopoulos S, Jerums G, Comper WD: Fractional clearance of albumin is influenced by albumin degradation. Clin Sci 1997;93:557-564.

3 Osicka TM, Pratt LM, Comper WD: Glomerular capillary wall permeability to albumin and horseradish peroxidase. Nephrology 1996;2: 199-212.

4 Burne MJ, Osicka TM, Comper WD: Fractional clearance of high molecular weight proteins in conscious rats using a continuous infusion method. Kidney Int 1999;55:261-270.

5 Burne MJ, Panagiotopoulos S, Jerums G, Comper WD: Alterations in renal degradation of albumin in early experimental diabetes: A new factor in the mechanism of albuminuria. Clin Sci 1998;95:67-72.

6 Osicka TM, Yu Y, Panagiotopoulos S, Clavant SP, Kiriazis Z, Pike RN, et al: Prevention of albuminuria by aminoguanidine or ramipril in STZ diabetic rats is associated with the normalisation of glomerular protein kinase C. Diabetes 2000;49:87-93.

7 Osicka TM, Kiriazis Z, Pratt LM, Jerums G, Comper WD: Ramipril and aminoguanidine restore lysosomal processing in streptozotocin diabetic rats. Diabetologia 2001;44:230-236.

8 Osicka TM, Houlihan CA, Chan JG, Jerums G Comper WD: Albuminuria in patients with type 1 diabetes is directly linked to changes in the lysosomal-mediated degradation of albumin during renal passage. Diabetes 2000;49: 1579-1584.

9 Maunsbach AB, Dingle JT, Fell HB (eds): Lysosomes in Biology and Pathology. Amsterdam, North-Holland, 1969, vol 1, pp115-154.

10 Baricos WH, Zhou Y, Fuerst RS, Barrett AJ, Shah SV: The role of aspartic and cysteine proteinases in albumin degradation by rat kidney cortical lysosomes. Arch Biochem Biophys 1987;256:687-691.

11 Vyas SV, Burne MJ, Pratt LM, Comper WD Glomerular processing of dextran sulphate. Arch Biochem Biophys 1996;332:205-212.

12 Burne MJ, Adal Y, Cohen N, Panagiotopoulos S, Jerums G, Comper WD: Anomalous decrease in dextran sulfate fractional clearance in the diabetic rat kidney. Am J Physiol 1998;43: F700-F708.
13 Tack BF, Dean J, Eilat D, Lorenz PE, Schecter AN: Tritium labelling of proteins to high specific radioactivity by reductive methylation. $\mathrm{J}$ Biol Chem 1980;255:8842-8847.

14 Eng LA: Production and characterization of $\left[{ }^{14} \mathrm{C}\right]$ protein $\mathrm{A}$, a long-lived immunological reagent. J Immunol Methods 1985;81:239-243.

15 Wiig H, De Carlo M, Sibley L, Renkin EM: Interstitial exclusion of albumin in rat tissues measured by continuous infusion method. Am J Physiol 1992;263:H1222-H1233.

16 Wiig H, Kaysen GA, Al-Bander HA, De Carlo M, Sibley L, Renkin EM: Interstitial exclusion of $\mathrm{IgG}$ in rat tissues estimated by continuous infusion. Am J Physiol 1994;266:H212-H219.

17 Di Giorgio J: Non-protein nitrogenous constituents; in Clinical Chemistry. Principles and Techniques. Baltimore, Harper \& Row, 1974, pp 503-563.

18 Rowland M, Tozer TN: Clinical Pharmacokinetics: Concepts and Applications, ed 3. Philadelphia, Lippincott Williams \& Wilkins, 1995.

19 Kaysen GA, Watson JB: Mechanism of hypoalbuminemia in the 7/8-nephrectomized rat with chronic renal failure. Am J Physiol 1982;243: F372-F378

20 Greenwood FC, Hunter WM, Glover JS: The preparation of ${ }^{131}$ I-labeled human growth hormone of high specific radioactivity. Biochem $\mathrm{J}$ 1963;89:114-123.

21 Gornall AG, Bardawill CJ, David MM: Determination of serum proteins by means of the biuret reaction. J Biol Chem 1949;177:751766.

22 Fox S: Application of Triton X-100 colloid scintillation counting in biochemistry. Int $\mathrm{J}$ Radiat Isot 1968;19:717-730.

23 Eppel GA, Takazoe K, Nikolic-Paterson DJ, Lan HY, Atkins RC, Comper WD: Characteristics of albumin processing during renal passage in anti-thy 1 and antiglomerular basement membrane glomerulonephritis. Am J Kidney Dis 2000;35:418-426.

24 Osicka TM, Hankin AR, Comper WD: Puromycin aminonucleoside nephrosis results in a marked increase in the fractional clearance of albumin. Am J Physiol 1999;46:F139-F145.

25 Greive KA, Nikolic-Paterson DJ, Guimarães MAM, Nikolovski J, Pratt LM, Mu W, Atkins RC, Comper WD: Glomerular permselectivity factors are not responsible for the increase in fractional clearance of albumin in rat glomerulonephritis. Am J Pathol 2001;159:1159_ 1170 .
26 Sabatino B, Van Liew JB: The renal handling of $\mathrm{IgG}$ in the aging rat and in experimental kidney disease. Proc Soc Exp Biol Med 1997;216:414423.

27 Myers BD, Nelson RG, Tan M, Beck GJ, Bennett PH, Knowler, Blouch K, Mitch WE: Progression of overt nephropathy in non-insulindependent diabetes. Kidney Int 1995;47:17811789 .

28 Gilbert RE, Akdeniz A, Jerums G: Detection of microalbuminuria in diabetic patients by urinary dipstick. Diabetes Res Clin Pract 1997 35:57-60.

29 Vangelisti S, Parravicini R, Masi I, Bertoni C, Matteucci E, Giampietro O: The reliability of urinary albumin assay by immunonephelometry in clinical practice. Acta Diabetol 1997;34 22-26.

30 Bolton GR, Deen WM, Daniels BS: Assessment of charge-selectivity of glomerular basement membrane using Ficoll sulfate. Am J Physiol 1998;274:F889-F896.

31 Bray J, Robinson GB: Influence of charge on filtration across renal basement membrane films in vitro. Kidney Int 1984;25:527-533.

32 Comper WD, Glasgow EF: Charge selectivity in kidney ultrafiltration. Kidney Int 1995;47: 1242-1251.

33 Russo LM, Bakris GL, Comper WD: Rena handling of albumin: A critical review of basic concepts and perspective. Am J Kidney Dis 2002;39:899-919.

34 Eppel GA, Osicka TM, Pratt LM, Jablonski P, Howden BO, Glasgow EF, Comper WD: The return of glomerular-filtered albumin to the rat renal vein. Kidney Int 1999;55:1861-1870.

35 Shechter P, Boner G, Rabkin R: Tubular cell protein degradation in early diabetic renal hypertrophy. J Am Soc Nephrol 1994;4:15821587.

36 Schaefer L, Schaefer RM, Ling H, Teschner M, Heidland A: Renal proteinases and kidney hypertrophy in experimental diabetes. Diabetologia 1994;37:567-571.

37 Olbricht CJ, Geissinger B: Renal hypertrophy in streptozotocin diabetic rats: Role of proteolytic lysosomal enzymes. Kidney Int 1992;41: 966-972.

38 Teschner M, Schaefer RM, Svarnas A, Heidland U, Heidland A: Decreased proteinase activity in isolated glomeruli of streptozotocin diabetic rats. Am J Nephrol 1989;9:464-469. 